\section{15
py 2 \\ 995
15
py 2 \\ 995
15
py 2 \\ 995
15
py 2

$$
15
$$

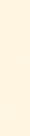<smiles>CCC</smiles>

.

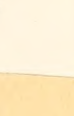

(
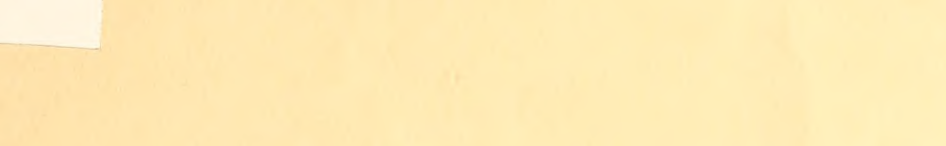

SB 995

B15

Copy 2

\section{HUW BIRDS AFFECT THE FARM AND GARDEN.}

A SERIES OF FACTS DEIERMINED BY INVESTIGATION OF THE FOOD HABITS OF OUR COMMON BIRDS, SHOWING 'THEIR

CHARACTER AS INSECT DESTROVERS AND THEIR

VALUE AS ALLIES OF THE FARMER

AND FRUTT GROWER.

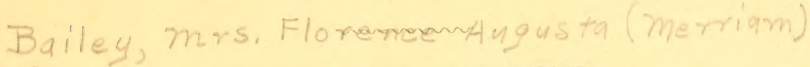

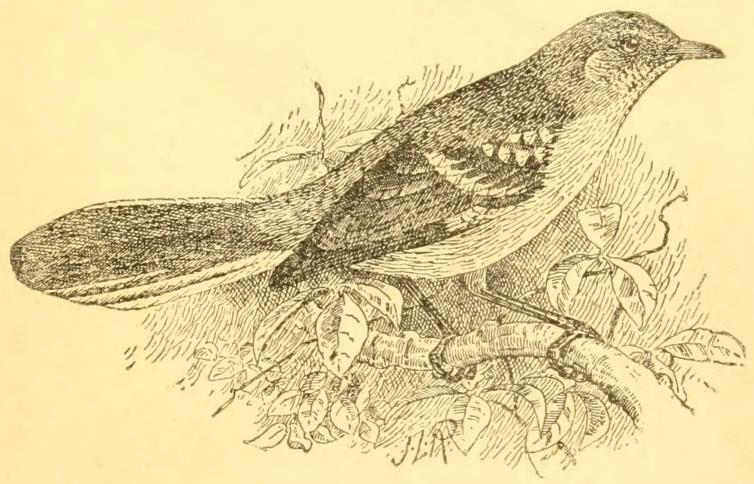

THE MOCKINGBIRD.

Reprinted from "Forest and Stream."

NEW YORK :

Forest and Streami Publishing Company, 346 Broadway. 
Copyright, r836, by

Forest and Stream Publishing Company

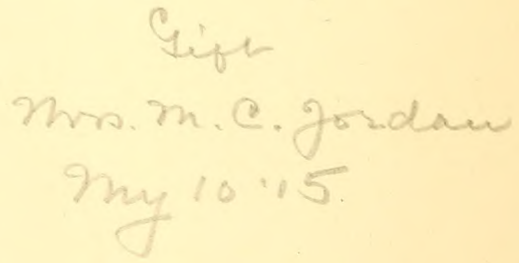

$\because \vdots$

Copies of this booklet in quantities of one hundred or more will be supplied at cost to societies and individuals for distribution. 


\section{BIRDS AND FARMERS.}

From the Forest and Stream.

THE advocates of protection for our small birds present two sets of reasons for preventing their killing: the one sentimental, and the other economic.

The sentimental reasons are the ones most often urged; they are also of a kind to appeal with especial force to those whose responsibility for the destruction of the birds is greatest. The women and girls, for whose adornment birds' plumage is chiefly used, think little and know less about the services which birds perform for agriculture, and indeed it may be doubted whether the sight of a bunch of feathers or a stuffed bird's skin suggests to them any thought of the life that those feathers once represented. But when the wearers are reminded that there was such a life; that it was cheery and beautiful, and that it was cut short merely that their apparel might be adorned, they are quick to recogniz 3 that bird destruction involves a wrong, and are ready to do their part toward ending it by refusing to wear plumage.

The small boy, who pursues little birds from the standpoint of the hunter in quest of his game, feels only the ardor of pursuit. His whole mind is concentrated on that and the hunter's selfishness, the desire of possession, fills his heart. Ignorance and thoughtlessness destroy the birds.

Every one knows in a general way that birds render most valuable service to the farmer, but although these services have long been recognized in the laws standing on the statute books of the various States, it is only within a few years that any systematic investigations have been undertaken to determine just what such services are, to measure them with some approach to accuracy, to weigh in the case of each species the good and the evil done, and so to strike a balance, in favor of the bird or against it. The inquiries carried on by the Agricultural D partment on a large scale and those made by various local experiment stations and by individual observers have given results which are very striking and which can no longer be ignored. Some of these results Miss Merriam gives in her paper prepared for FOREST AND STREAM. It deserves careful study, not only by every farmer, but also by every one who is at all interested in birds or in agriculture in any form. At a time like this, when reports of the ravages of army worms, elm beetles and other noxious insects are constantly heard, a paper such as this has a deep interest for a very large class. Miss Mer- 
riam's articles, besides being written in graceful, simple and popular style, give in small compass the results of many papers which have appeared in different reports, not all of them easily accessible, and these reports are of ten so technical as to be quite beyond the grasp of the general reader. A wide circulation of Miss Merriam's paper would do much to arouse an intelligent appreciation among agriculturists of the vast good done by many species of birds, and would greatly benefit the country.

It is a difficult matter for any one to balance the good things that he reads and believes about any animal against the bad things that he actually sees. The man who witnesses the theft of his cherries by robin or catbira, or the killing of a quail by a marsh hawk, feels that here he has ocular proof of harm done by the birds, while as to the insects or the field mice destroyed, and the crops saved, he has only the testimony of some unknown and distant witness. It is only natural that the observer should trust the evidence of his senses, and yet his eyes tell him only a small part of the truth, and that small part a misleading one.

It is certain that without the services of these feathered laborers, whose work is unseen, though it lasts from day. light till dark through every day in the year, agriculture in this country would come to an immediate standstill, and if in the brief season of fruit each one of these workers levies on the farmer the tribute of a few berries, the price is surely a small one to pay for the great good done. Superficial persons imagine that the birds are here only during the summer, but this is a great mistake. It is true that in warm weather, when insect life is most abundant, birds are also most abundant. They wage an effective and unceasing war against the adult insects and their larvæ, and check their active depredations; but in winter the birds carry on a campaign which is hardly less important in its results. It is then that the chickadee, the nuthatch, the brown creeper, the kinglets and the woodpeckers are hard at work all through the short days, searching the crevices and crannies in the bark of the tree trunks and branches, looking among the undergrowth, hunting along the fences for the bunches of eggs, the buried larvæ and the pupæ of the insects, which if undisturbed would, when warm weather comes, hatch out millions of creeping, crawling and fiying things that would devastate garden and orchard and every crop of the field. It is through this silent, unceasing work by the birdssome in summer and others in winter-that the insect hosts are held in check. 


\title{
HOW BIRDS AFFECT THE FARM AND GARDEN.
}

\author{
BY FLORENCE A. MERRTAN。
}

IT is said that two hundred millions of dollars that should go to the farmer, the gardener and the fruit grower in the United States, are lost every year by the ravages of insects-that is to say, one-tenth of our agricultural products is actually destroyed by them. The ravages of the gypsy moth in three counties in Massachusetts for several years annually cost the State $\$ 100,000$. Now, as rain is the natural check to drought, so birds are the natural check to insects, for what are pests to the farmer are necessities of life to the bird. It is calculated that an average insectivorous bird destroys 2,400 insects in a year; and when it is remembered that there are over 100,000 kinds of insects in the United States, the majority of which are injurious, and that in some cases a single individual in a year may become the progenitor of several billion descendants, it is seen how much good birds do ordinarily by simple prevention.

The good they do in cases of insect plagues, like that of the grasshopper scourge in Nebraska and Kansas, is still more marked. Then, as self-constituted militia, they fly to the scene of action and make away with the rioters. An interesting case of this kind was seen in an old orchard in Illinois. The cankerworm had so taken posses. sion that the orchard looked almost as if overrun with fire. Forty different kinds of birds assembled in the place to feed upon the worms. One hundred and fortyone of the birds were shot and the contents of their stom. achs examined; more than one-third of their food was found to have been cankerworms - the feathered army was simply wiping out the horde of worms. A similar case occurred in Massachusetts, and after the visit of the birds a good crop of apples was raised in the orchard which had been devastated.

It is well known that of the various groups of birds the majority live upon insects. Among the insect eaters are the flycatchers, warblers, woodpeckers, nuthatches, orioles, goatsuckers, hummingbirds, tanagers, waxwings, gnatcatchers, kinglets, vireos, thrushes, wrens, titmice, cuckoos, swallows, shrikes, thrashers, creepers and bluebirds.

It is not generally known, however, that the so-called seod eaters feed their young largeily upon insects, arid eat 
a great many themselves; nor is it realized how much good they do by eating weed seeds. Prof. F. E. L. Beal has calculated that the little tree sparrow in Iowa alone destroys $1,720,000 \mathrm{lbs}$. of noxious weed seeds every year. Moreover, in summer seed eaters eat blueberries, huckleberries, strawberries and raspberries, and distribute their seeds unharmed over thousands of acres which would not otherwise support such growth.

These facts show how important it is that the birds should be protected and encouraged, except in the exceedingly few cases where for a few weeks they eat some one cultivated crop to such excess that the loss is not compensated by the good they do in destroying pests the rest of the year. The Department of Agriculture, realizing the losses that might result from the ignorant sacrifice of useful birds, constituted the Division of Economic Ornithology a court of appeal where accusations against the birds could be received and investigated.

The method used by the division is the final one-the examination of stomach contents to prove the actual food of the birds. A collection of 26000 stomachs has been made by the co-operation of hunters and collectors who have shot the birds for other purposes, and a reference collection of 800 kinds of seeds and 500 beetles and many other insects has been brought together for comparison in determining the character of food remains found. Al-
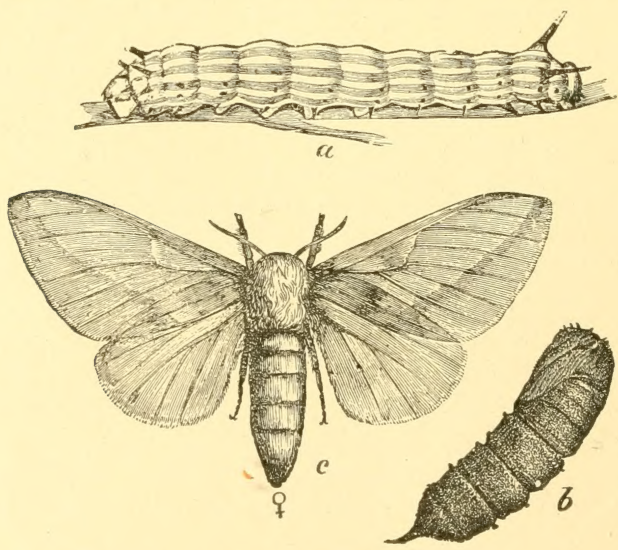

MAPLE CATERPILLAR. 
ready about forty different kinds of birds have been examined and reported upon. The examinations have been made chiefly by Prof. Walter B. Barrows, Prof. Otto Lugger, Mr. E. A. Schwarz, Dr. A. K. Fisher, Prof. F. E. L, Beal and Mr. Sylvester D. Judd, with the assistance of the late Prof. C. V. Riley and Mr. L. O. Howard, now chief entomologist of the Department of Agriculture. The reports already printed or about to be issued by the Division of Ornithology are the reports of the ornithologist for the years $1886,1887,1888,1889,1890,1891,1892$ (with notes on the Food Habits of the Cedar Bird and Horned Lark), 1893 (with notes on the Food of the Kingbird), 1894 (with articles on the Crow Blackbirds and their Food, and Hawks and Owls from the Standpoint of the Farmer); Bulletin No. 1, The English Sparrow, by Walter B. Barrows; Bulletin No. 3, Hawks and Owls, by Dr. A. K. Fisher; Bulletin No. 6, The Common Crow of the United States, by Walter B. Barrows and E. A. Schwarz (1895); Bulletin No. 7, Preliminary Report on the Food of Woodpeckers, by F. E. L. Beal (1895); Four Common Birds of the Farm and Garden, by Sylvester D. Judd; The Meadowlark and Baltimore Oriole, by F. E. L. Beal; The Food Habits of the Kingbird, by Walter B. Barrows; The Cedar Bird, by F. E. L. Beal.

After the examination of about forty birds, the only one actually sentenced to death is the English sparrow. Of all the accused hawks only three have been found guilty of the charges made against them-the goshawk, Cooper's and the sharp-shinned-while the rest are numbered among the best friends of the fruit grower and farmer. Of the woodpeckers, the sapsucker and redhead may be beneficial or injurious, according to circumstances, but the rest of the family are highly beneficial. To most of the remaining birds tried the evidence is decidedly creditable. The crow, crow blackbird and cedar bird are acquitted as doing more good than harm; and it is proved that agriculturists owe especial protection and friendship to the phœbe, kingbird, catbird, swallow, brown thrasher, rose-breasted grosbeak, house wren, vireos, cuckoo, oriole, shore lark, loggerhead shrike and meadowlark.

\section{Catbird.}

The catbird is persecuted because it eats fruit; but, although stomach examinations show that it does eat considerable in some parts of the country, one-third of its food consists of insects which annually destroy a large part of the farmer's profits. As Mr. Judd, in speaking of 
the catbird, says: "By killing the birds their services as insect destroyers would be lost, so the problem is to keep both the birds and the fruit." The study of this matter has led to one of the most important discoveries made in the investigations of the Division of Ornithology. It has been demonstrated that some birds --the catbird among the number-actually prefer wild fruits to cultivated, and that most of the complaints of depredations come

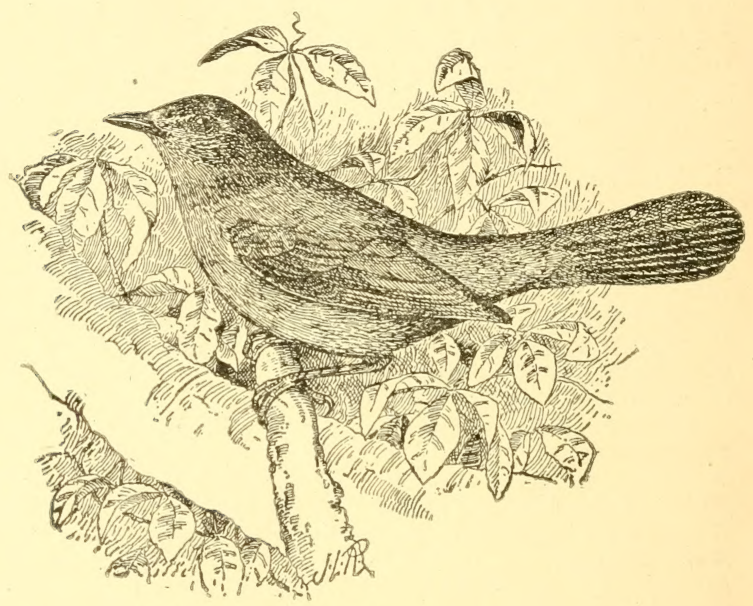

ATBIRD.

from parts of the country where there is little wild fruit, so that by planting berry-bearing bushes and trees it may be possible to prevent losses to cultivated fruits and at the same time to attract the birds and so secure their muchneeded help in destroying insect pests.

The catbird is an excellent example of this. Experiments show that he prefers the red mulberry to cherries and strawberriers, and stomach examinations show that he eats twice as mueh wild fruit as cultivated, while one-third of his food is made up of insects. A slight idea of the good he does in destroying pests may be had from the fact that thirty grasshoppers were found in each of five stomachs. Reports show that he does much more harm in the central United States, where wild fruits are 
scarce, than near the coast, where they are abundant. Mr. Judd suggests that the crops of chesries and straw. beries can be protected by planting the "prolific Russian mulberry, which, if planted in hen yards and pig runs. will afford excellent food for the hens and pigs besides attracting tho birds away from more valuable fruit."

The verdict in the case of the catbird is, that he is already one of the farmer's best assistants, and that by a little $\epsilon$ fiort the small amount of harm he does might be counteracted so that he would do unalloved good in the farm and garden.

\section{Kingbird.}

The kingbird has been so long accused of destroying honey bees that careful examinations have been made of 218 stomachs. Insects formed about 90 per cent. of the whole food, but only fourteen of the 218 stomachs cor. tained any trace of honey bees. Furthermore, nearly all the bees found were drones. On the other hand, the

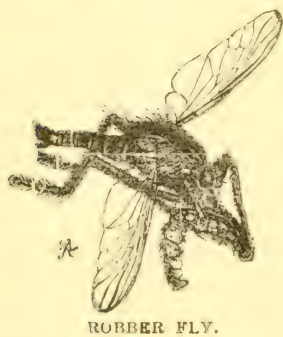
cloverleaf weevil, the destructive rosechafer, anti and grasshoppers.

Of the little fruit the kingbird eats, only three or four kinds are cultivated, and if he were to harm one kind of fruit it would be easy to plant something that he would eat instead, as he feeds on wild red and black cherries, choke cherries, elderberries, mulberries, wild grapes, spice bush, sassairas, cornel, red and ground cedar, buck. thorn, magnolia and pokeberry.

The conclusion reached from the examination of the 218 stomachs is that the kingbird is one of the best helps the farmer has in the destruction of harmful insects. One correspondent exclaims fervertly, "I honor and esteem this bird for the millions of ruinous vermin he riss. us of!" 


\section{Swallows.}

The swallows are probably the greatest flycatchers in the eastern United States, but in addition to this they destroy great numbers of flying ants, aquatic leaf-eating beetles and weevils.

\section{Barn Swallow.}

Mr. Judd says, "The barn swallow is the most noted destroyer of flies, especially those kinds which torment stock."

\section{Eave Swallow.}

This useful bird builds under the eaves of our barns and eats enormous quantities of winged ants and also mosquitoes, injurious wheat midges, spotted squash beetles, and beetles that work under the bark of trees.

\section{Chickadee.}

In an article on "Birds as Protectors of Orchards," Mr. E. H. Forbush, of the Massachusetts Board of Agriculture, says of the chickadee: "There is no bird that can compare with it in destroying the female cankerworm moths and their eggs." Hø calculated that one chickadee in one day would destroy 5,550 eggs, and in the twentyfive days in which the cankerworm moths run or crawl up the trees 135,750 eggs. Mr. Forbush attracted chickadees to one orchard by feeding them in winter, and he says that in the following summer "it was noticed that while trees in neighboring orchards were seriously infested with cankerworms and to a less degree with tent caterpillars, those in the orchard which had been frequented by the chickadees during the winter and spring were not seriously infested, and that comparatively few of the worms and caterpillars were to be found there." His conclusion is that birds that eat eggs of inseats are of the greatest value to the farmer, as they feed almost entirely on injurious insects and their eggs, and are present all winter, when other birds are absent.

\section{Cedar Bird.}

The cedar bird is also known as the cherry bird, but cultivated cherries have been found in only nine out of 152 stomachs examined, which, as Prof. Beal says, "hardly justities the reputation which the bird has gain हd as a destroyer of cherries." He adds that this supposed cherry habit "to the careless and unobservant would condemn the bird to destruction, but the closer observer looks further." Investigation shows that more than half of the 
whole food of the cerar bird consists of wild fruit which has no value, and that one-eighth of its foou consists of insects, among which are some of the worst pests of the country. Furthermore, since the nestlings are fed largely on insects, the greatest number of insects are eaten when fruit is most abundant. The cedar bird eats caterpillars, spiders and grasshoppers, but does most marked good in destroying the elm leaf beetle that strips our village and city trees of leaves. Mrs. Mary Treat writes of one town in which the elms had been ruined for several years before the cedar birds came, and which were afterward comparatively free from beetles. From one calculation it is shown that thirty cedar birds wculd destroy 9,000 worms during the month when the cut-worm caterpillar is exposed.

To prevent the cedar bird from eating cultivated fruit and to attract it to secure its help in destroying caterpillars it would be well to plant the common bushes upon whose berries it feeds, such as blackberry, wild cherry, choke cherry, sour gum, flowering dogwood, rough-leaved dogwood, cholkeberry, red cedar, June berry, hackberry, black haw, black elder, huckleberry, frost grape, barberry, mistletoe, or pokeberry.

\section{Crow.}

The charges against the crow are (1) that it pulls sprouting corn; (2) that it injures corn in the milk; (3) that it destroys cultivated fruit, and (4) that it feeds on the eggs and young of poultry and wild birds.

Nine hundred stomachs have been examined, but while it has been found that the crow does eat the forbidden food, it has also been seen that the quantity he eats is so small that it is more than counterbalanced by the good he does in destroying injurious insects and harmful animals. Only 3 per cent. of the total food of the crow is sprouting corn and corn in the mills; the rest that he is credited with is mostly waste grain picked up here and there mainly in winter, and so of no economic value. The injury the crow does to cultivated fruits is trivial. Moreover, the eggs and young of poultry and wild birds which he eats constitute only 1 per cent. of his food for the year. The prejudice against him is based on an exaggeration of the harm he does, for in each instance it is proved to be insig. nificant.

Some intelligent farmers who realizg the money value of the services of the crows either feed them old corn during the time when the growing corn is in the milk or else tar the corn before planting, in both cases protecting 
themse. res rrom the injury the birds may do, and at the same time insuring their help in destroying the pests that will surely menace the maturing crop. Tarring must be done carefully to be successfuil. The best methods are given in the Crow Bulletin (No. 6), pp. 89-91.

But while protecting ourselves from the possible sins of the crow we must credit him with the good he does; 20 per cent. of his entire food consists of insects, the majority of which are grasshoppers, May beetles, cut worms and other injurious kinds. Another of the most important items of the crow's food is mice, and when rabbits and other harmful rodents are added to the list it becomes obvious that the good the bird does exceeds the bad, and that he is deserving the patient encouragement of the farmer. When we consider the work the crow does as a scavenger, our debt to him becomes still more apparent.

It has been well said that we do not shoot our cows and horses, although they cat our grain throughout the year: and it seems strange indeed that we should be unwilling to feed the birds during a few weeks when they spend the resi of the sumner as unpaid day laborers in our farms and gardens, freeing us from pests which threaten to destroy all our profits.

\section{Bluejay.}

Like the crow, the bluejay is accused of pulling corn and eating young birds and eggs; 280 stomachs have been examined. Of these, remains of birds' eggs were found. in only three, and of birds in two ; 7 per cent. of the food of the year was found to be corn, but on the other hand 22 per cent. was made up of insects, such as grasshoppors and caterpillars, which shows that the jay does moro buod than harm.

[n the matter of grain, the jay seems to take corn when nothing betrer offers, but evidently prefers mast, the largo seeds of trees and shrubs, such as acorns, chestnuts, beerhnuts and hazelnuts. This preference is shown by the fact that in the two months whon the most corn is to be had-October and November-the bluejay stomachs shuw only 1 per cent. of coin against 64 per cent. of mast. Moreover, when corn is actually thrown out to the jay, as it of ten is on beds of chaff by New England farmers in winter, the momont the bare spots appear so that he can pick up his favorite food from the ground he deserts the corn.

The conclusion is that the biuejay has been unduly censired in the matter of eating yoing bixds and eggs. 
and that, as he does not eat corn wheu he can obtain rasi, he does less harm in eating corn than gond in destroying insects.

$$
\text { House Wren. }
$$

The house wien is exclusively inseurivorous and there. fore highly beneficial. Balf of its food is grasinoppere and beotles; it also dentroys ants, cavespillars, bugg, crickets and spiders.

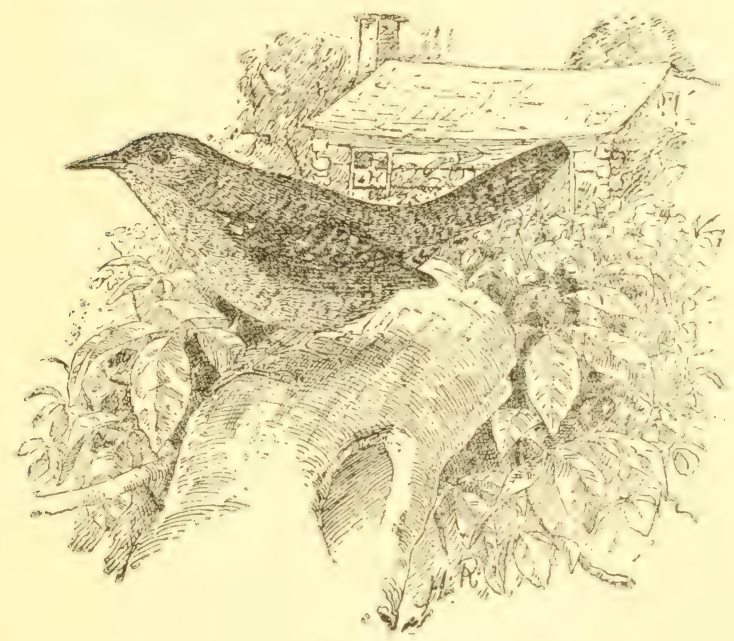

ROUSW WRRN

\section{Cuckoo.}

The cuckoo eats so many caterpiliars that the walls of its stomach are filled with hairs, makisg them lock like pieves of felt hat. One cuckoo was found with forty. three caterpillars in its stomach.

$$
\text { Black-Billed Cuckoo. }
$$

In sixteen stomachs examined the 6 were 328 caterpillars. fifteen grasshoppers, spiders, etc. The caterpillare were most of them hairy ones, many of them of a kind that lives in colonies and feeds on the leaves of apple and other trees. 


\section{Yellow-Billed Cuckoo.}

In twenty-one stomachs there were 355 caterpillars, twenty-three grasshoppers, saw flies, potato bugs, locusts, etc. One stomach contained twelve tent caterpillars, and another had 217 fall web worms.

\section{Oriole.}

Green corn has been found in one of 113 stomachs and peas in two; but one man who reports that the bird eats grapes adds that it is worth its weight in gold as an insect destroyer. Mr. Lawrence Bruner, in his "Notes on Nebraska Birds," well says: "If we take pains to water our birds during the dry season, they will be much less apt to seek this supply from the juices of fruits that are

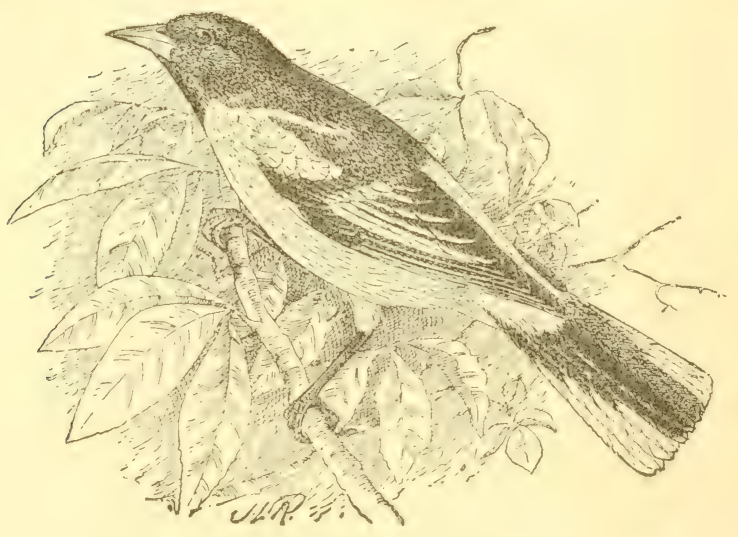

BALTIMORE ORIOLE.

so temptingly near at hand. Place little pans of water in the orchard and vineyard where the birds can visit them without fear of being seized by the house cat or knocked over by a missile from the alert 'small boy,' and I am sure that the injury to fruit to a great extent at least will cease." Speaking of the Baltimore oriole he adds: "As insect destroyers, both this bird and the orchard oriole have had an undisputed reputation for many years; and the kind of insects destroyed by both are of such a class as count in their favor." 
Prof. Beal says: "The oriole is a most potent factor in the destruction of caterpillars, eating so many that if no other insects were taken it would still be classed as a useful bird. It does not, however, restrict its diet to caterpillars, but eats great numbers of injurious beetles and also many bugs and grasshoppers, including beetles that feed on locust and apple trees, and the wire worm, one of the most destructive insects with which the farmer has to contend. In fact the oriole is one of the most useful birds that we have."

\section{Horned Lark; Shore Lark.}

It has been complained that the lark eats newly planted wheat and oats, but the examination of fifty-nine stomachs shows that it does not do any appreciable damage to grain crops, and on the other hand it does great good by eating weed seed. As Professor Beal says, "Any bird which eats freely the seeds of such pests as pigweed, bitterweed, amaranth and sorrel should be given the most perfect protection unless it is clearly shown to have bad habits which offset the benefit thus conferred."

\section{Butcherbird.}

The butcherbird comes South into the Uniled States in winter, and does good by destroying grasshoppers, mice and English sparrows.

\section{Loggerhead Shrike.}

This shrike is the common United States butcherbird. In the summer he lives on insects-98 $\mathrm{p}$ ?r cent. of the food for July and August in eighty-eight stomachs consisted of insects, mainly grasshoppers. In winter, when insects are scarce, the shrike becomes carnivorous; indeed, mice form 11 per cent. of the food for the year.

As will be inferred, the beneficial qualities of the shrike far outweigh the injurious.

\section{Rose-Breasted Grosbeak.}

This beautiful bird has shown itself of especial importance to the farmer because of its fondness for potato beetles, and should be protected and encouraged in every way.

$$
\text { Red-Winged Blackbird. }
$$

Nir. Lawrence Bruner says, "In the red-winged blackbird we bave a friend that we little dream of when we see the large flocks gathering about our cornfields during late summer and early fall. During the balance 
of the year it is engaged most of the time in waging war upon various insect pests, including such forms as the grub worms, cut-worms, grasshoppers, army worm, beet caterpillar, etc. Even when it visits our cornfields it more than pays for the corn it eats, by the destruction of the worms that lurk under the husks of the large per cent of the ears in every field.

"Several years ago the beet tields in the vicinity of Grand Island were threatened with great injury by a certain caterpillar that had nearly defoliated all the beets growing in many of them. At about this time large flocks of this bird appeared, and after a week's sojourn the caterpillar plague had vanished."

In winter the red-winged blackbird serves the farmer by destroying seeds of ragweed, foxtail grass and bindweed, while all through the summer it does great good by "destroying myriads of catexpillars, grasshoppers and weevils. Indeed it is without a peer as an enemy to one of our most injurious classes of insects-the weevils."

\section{Phœbe.}

The phobe lives mainly upon animal food. It destroys some useful irsects, but does more good than harm by eating numbers of weevils, so injurious to peas, beans and wheat; and also by reducing the number of flies, bugs, May beetles, caterpillars, squash beetles, elm-leaf beetles and grasshoppers.

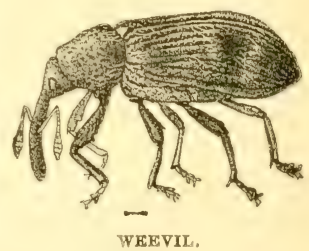

\section{Wood Pewee.}

The yewee, like its relative, the phøebe, feeds largely on the family of flies to which the house fly belongs.

$$
\text { Yellow-Bellied Flycatcher. }
$$

This little flycatcher does good by catching the injurious weevils.

\section{Vireos.}

The greenlets may be found from morning till night searching among the leafy treetops for insects both in our forests and in our villages and towns. They probably rank next to the cuckoo in the destruction of caterpillars, and are also of great value from their fondness for buge and weevils. May beetles, inch worms and leaf-eating beetles. 


\section{Brown 'Ihrasher。}

Mr. Judd, in his report on the thrasher, says: "The fruit grower who sees tho birds Alocking into his cherry tree not only neglects to observe the birds sandwiching in with the luscious fruit dainty morsels of insects, but also n'verlooks the fact that when the cherry season is over thry

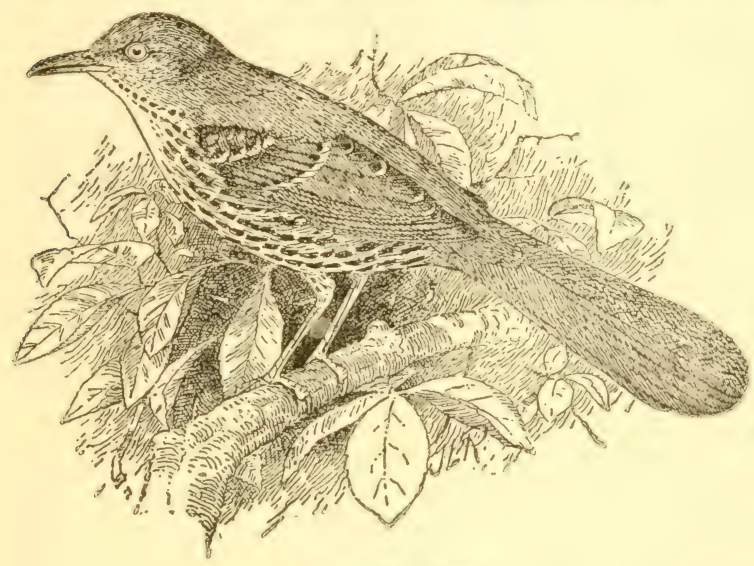

BROWN THRASEER.

raise havou with his worst enemies. The quantity of food taken from cultivated crops by the thrasher amounts to only 11 per cent.; of this 8 per cent. is fruit, and the rest grain. The farmer is more than compensated for this loss by the destruction of an equal bulk of May beetles, which, if allowed to live, would have done much more harm than the thrashers, and left a multitudinous progeny for next year."

\section{Crow Blackbird.}

Sometimes birds become too crowded in one place and their numbers need to be reduced. This is occasionally true of the crow blackbird, for when it descends upon a field in hundreds of thousands it inflicts real damage. But such instances are exceptional and can usually be prevented. One of the blackbird's commonest pursuits is to follow the plow, and after the birds have been doing it their stomachs are found "crammed with grubs." They 
also eat the destructive rose bug, curculio, May beetle, grasshopper, cricket and locust. Indeed, Professor Beal's

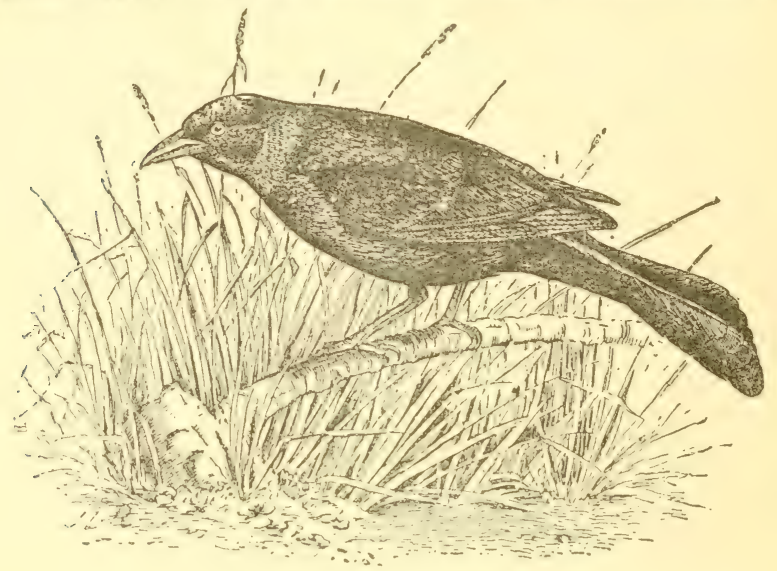

CROW BLACKBIKD.

conclusion is that "By destroying insects they do incalculable good."

\section{Robin.}

The robin is accused of eating cultivated fruits, but examinations show that less than 5 per cent. of his food is grown by man. As nearly half his food is wild fruit, it would be easy to substitute something for the garden products that he troubles. On the other hand, nearly half his food is animal, including wasps, ants, bugs, spiders, angleworms and a large per cent. of grasshoppers, crickets and caterpillars. Ho also eats great numbers of March fly larræ, so preventing much injury to the grass in the hay fields.

Professor Forbes asks this question: "Will the destruction of seventeen quarts of average caterpillars, including at least $\epsilon$ ight quarts of eut worms, pay for twenty-four quarts of cherries, blackberries, currants and grapes?" And Mr. Bruner says: "He is a poor business man who pays $\$ 10$ for that which he knows must later be sold for 15 cents or even less. Yet I have known of instances where a robin that had saved from ten to fifteen bushels 
of apples that were worth a dollar per bushel, by clearing the tree from canker worms in the spring, was shot when he simply pecked one of the apples that he had saved for the grateful or ungrateful fruit-grower."

The robin is such a favorite that it is interesting to know what wild fruits can be planted to attract him and draw his attention from the small fruits of the garden when he chances to take an undue amount. The wild fruits found in his stomach are dogwood, wild grape, wild black cherry, choke cherry, bird cherry, mulberry, greenbrier berry, cranberry, blueberry, huckleberry, holly berry, elderherry, hackberry, service berry, spice berry, hawthorn, bittersweet, Virginia creeper, moonseed, mountain ash, black haw, barberry, pokeberry, strawberry bush, junip $r$, persimmon, saw palmetto, California mistletoe and bayberry.

\section{Bluebird.}

More than three-quarters of the bluebird's food is animal, nearly a quarter of it being grasshoppers and crickets, and a tenth caterpillars.

There is no cultivated fruit on his list, but as he is a bird which everyone is anxious to attract, it is well to know for which wild fruits he seems to have a preference. $\mathrm{He}$ has been found to eat bird cherry, choke cherry, dogwood, bush cranberry, huckleburry, greenbrier, Virginia creeper, straw berry, juniper berry, bittersweet, pokeberry, false spikenard, partridge berry and wild sarsaparilla.

\section{Meadow Lark.}

It has been said that the meadow lark eats clover seed, but in looking for it in stomach contents it was found in

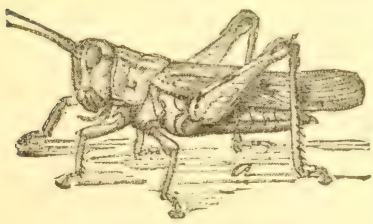

SMALL GRASSHOPPER. only six out of 238 stom. achs, and 99 per cent. of the food at clover time was found to be insects, mainly grass hop pers-insects whose ravages have been notorious from the earliest times. Prof. Beal says, "The number eaten is so enormous as to entitle the meadow lark to rank among the most $\epsilon$ fficient of our native birds as a grasshopper destroyer." It is estimated that the value of the grass crop saved by meadow larks on a township of thirty-six square miles each month during the grasshopper season is about $\$ 24$. 
s'Nor are the other components of the insect food less important except in quantity. Some of the most injuxious beetiles form a considersble percentage of the stomach.

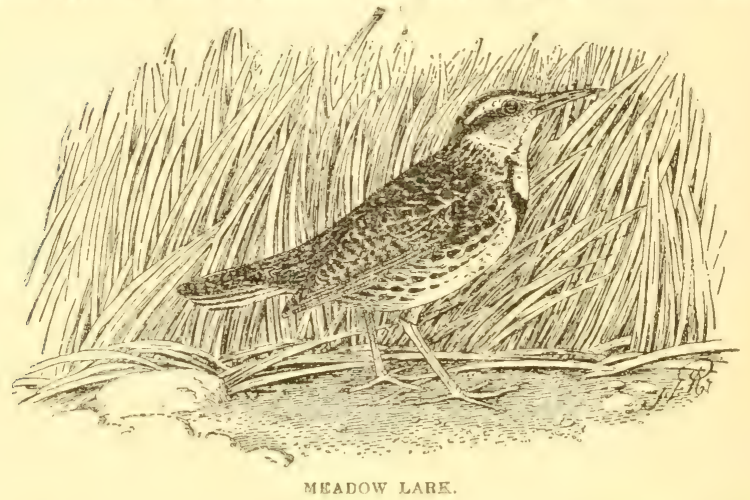

"ontents." Among other insects eatfn by the meadow lark are May beetles, ants, bugs, caterpillars, curculios and leaf beetles. In conclusion Prof. Beal says, "Far from heing injurious, it is one of the most useful allies to agricuiture, standing almost without a peer as a destroyer of noxious insects."

Woodpeckers.-Sapsucker.

The sapsucker has the habit of drilling holes in the bark of trees, and, as his name would indicate, sucks the sap that exudes from the tree. But this is not all, nor does it doom him to disfavor. Now and then an individual sapsucker may girdie and kill an ornamental birch on a lawn; but for one which does that, numbers are at work destroying the insects that gather at the sap on the hardy forest trees which the woodpecker will not harre. A description of the sapsucker's performance says, "As the sap ezudes from the newly-made punctures, thousands of flies, gellow jackets and other insects congregate about the place, till the hum of their wings suggests a swarm of bees. If now the tree be watched, the wnodpecker will soon bo seen to return and alight over the part of the girdle which ho has most recently punctured. Here he remains with motionless body and feeds upon the choicest species from a host of insects within easy reach." 
Some sapsuckers have been expevimented with to find out if they could live principally on syrup, but in each instance have died from the diel. Stomach examiaations hear ont the testimony. The sapsucker is thrgely an in-

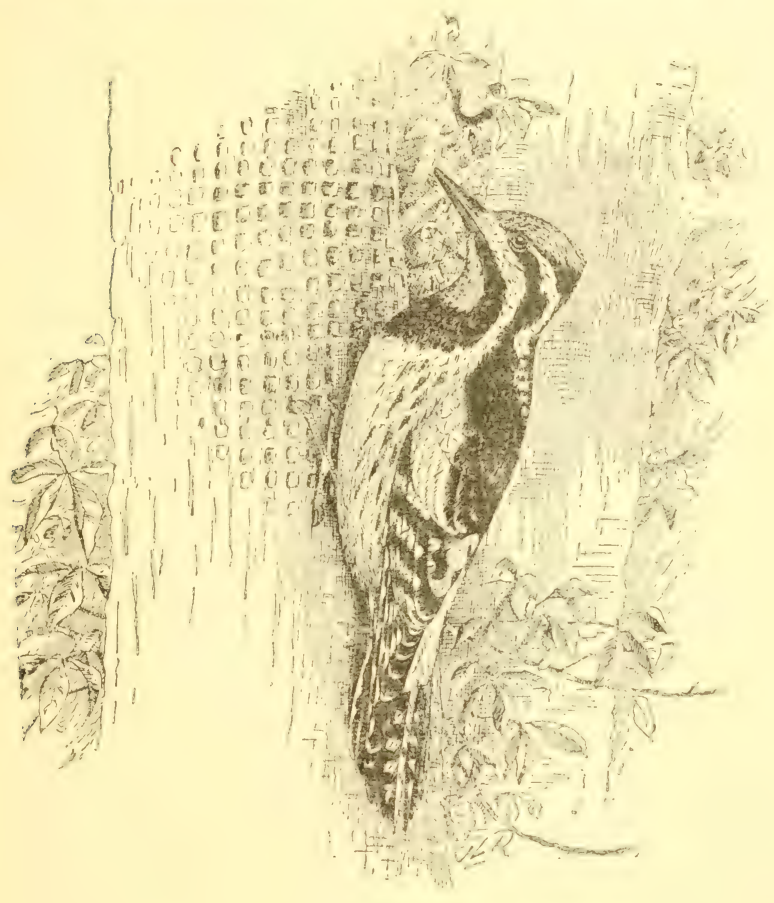

iAPSUCE bite.

sect eater, Thirty-six per cent. of bis soili food consists of ants. He also destroys waspa, beetles, bugs, ties, grasshowpers and crickets. He eats more ties than any other woodpecker. To keep him from ornamental trees it might be well to plant the dogwood, black alder. Vir. ginia creeper, wild black cherry and juripes. 


\section{Red-Headed Woodpecker.}

The redhead eats more grasshoppers than any other woodpecker. It also assists in destroying June bugs and weevills. In the North its main food is beechnuts. It does some harm by eating grain and fruit, but not enough

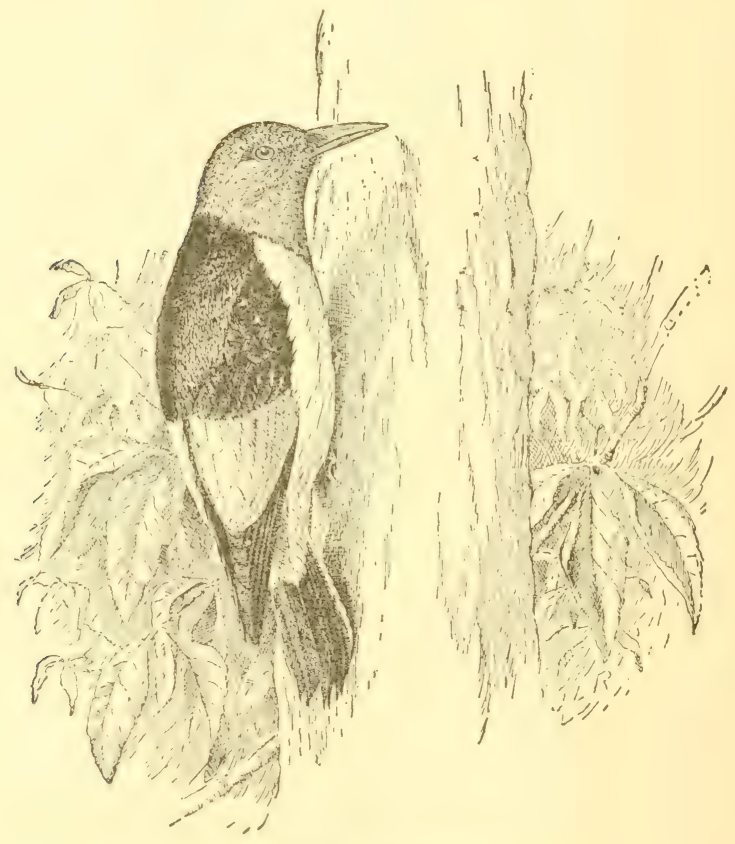

RED HEADED WOODPECKER.

to amount to much. As it eats a large quantity of wiid fruit, it could probably be diverted from the cultivated varieties by planting wild ones where they do not exist. The best would probably be dogwood, mulberry, elderberry, choke cherry and wild black cherry. 


\section{Flicker.}

Nearly half of the food of the flicker is ants, Thrce thousand were found in one stomach. As ants spread plant lice, destroy timber and infest iouses, the flicker is certainly a useful bird. It does good work in otlser ways

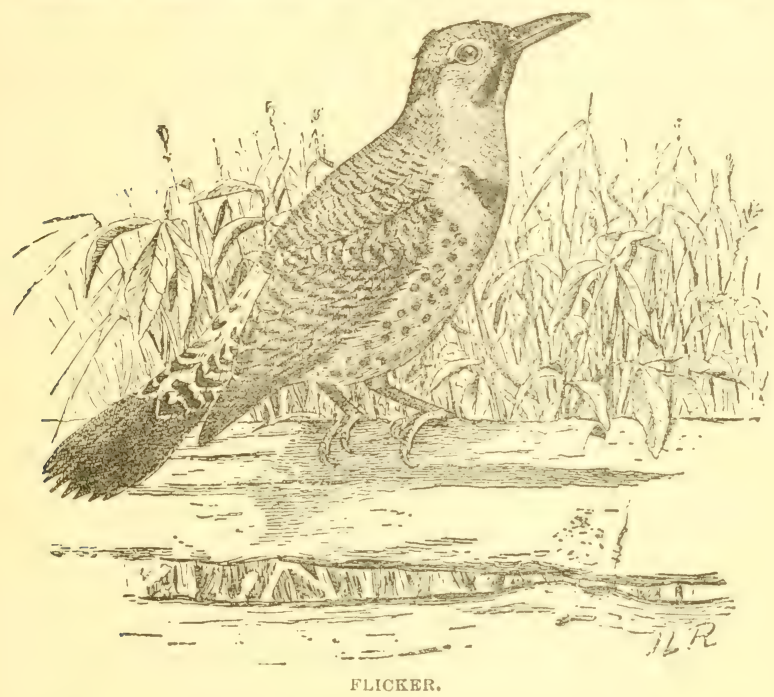

also. Like many innocent birds, the flicker has been accused of corn-eating, but only five out of $2: 30$ stomachs contained any corn.

Prof. Beal, hoving spoken of the good work the woodpeckers did in Nebraska at the time of the grasshopper devastation, says of the downy, hairy and flicker: "Not one of the trio shows a questionable trait, and they should be protected and encouraged in every possible way."

\section{Hairy Woodpecker.}

The hairy comes next to the downy in usefulness. It eats a large number of beetles and caterpillars, almost no grain, and only wild fruits. Sixty-eight per cent. of its food is animal, including ants, beetles, bugs, grasshoppers and spiders. 


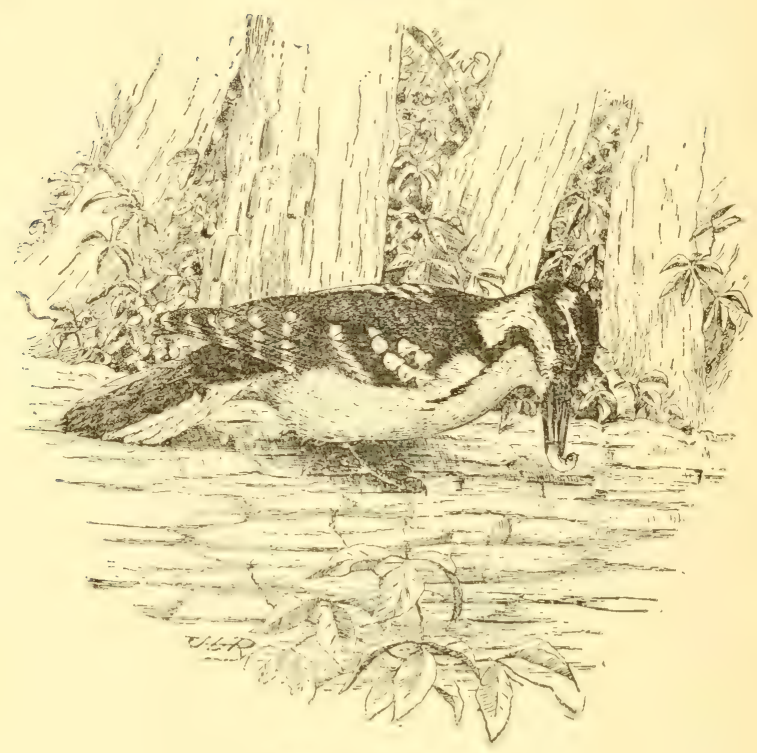

GAIRY WOODPECKER.

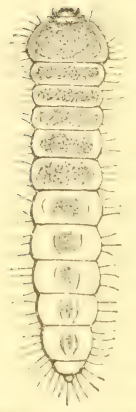

IREE-BORING TARVA.

\section{Downy Woodpecker.}

This little woodpecker, the sma!lest of the family, has been accused of eating fruit, but in 140 stomachs examined apple was found in only two and strawberries in one. On the other hand, almost 75 per cent. of the bird's food is insects. Eleven woodpeckers taken in Kansas in winter contained 10 per cent. of grasshopper eggs. The little bird also destroys May beetles, plant lice and ants. A single wood-borer will often kill an entire tree, and one-fifth of the downy's animal food consists of caterpillars, many of which bore into wood and live on stems and leaves. Indeed, the downy is the most beneficial of all the useful woodpecker family. 
Hawks and Owls.

In speaking of the injustice which has been done to many of the best friends of the farm and gasden, Dr. Fisher says: "The birds of prey, the majority of which labor night and day to destroy the enemies of the hus. bandmen, are persecuted unceasingly." There are only three common inland hawks in the United. States that do harm, and when this is understood it becomes most im. portant that they should be distinguished from those whose services are of value in order that the beneficial ones may not be killed by mistake. They are the goshawk, Cooper's hawk, and sharp-shinned bamk, of

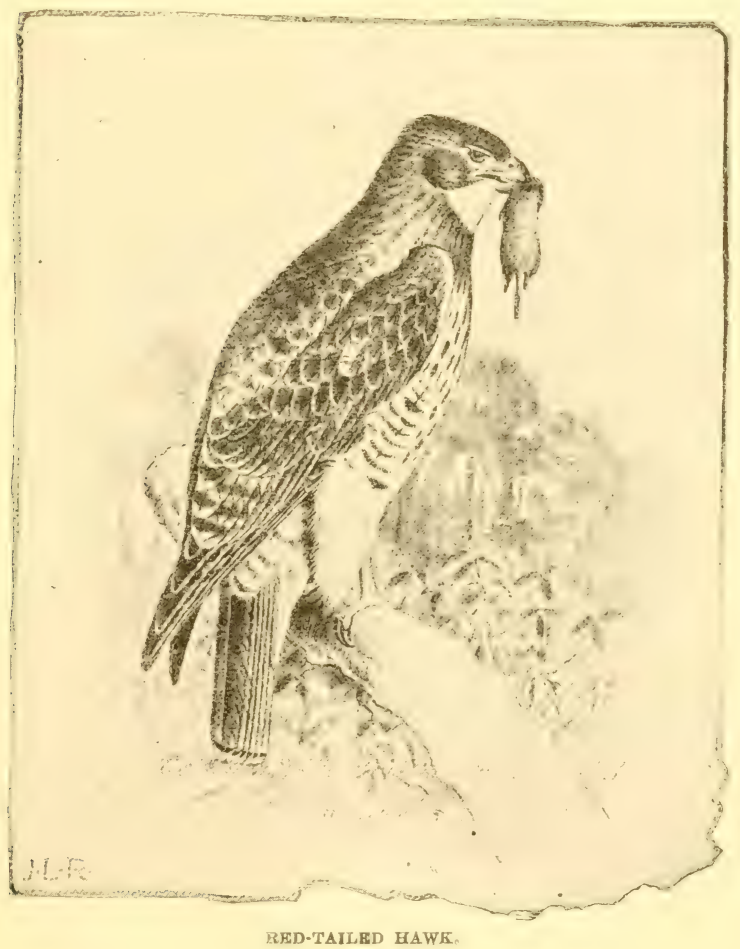


these, fortunately, the goshawk is rare in the United States except in winter. Cooper's hawk, or the chicken hawk, is the most destructive, especially to doves; and the sharp-shinned haw $\mathrm{k}$ is very destructive to small birds, 96 per cent, of its stomach contents consisting of birds. But about two-thirds of the birds of prey in the United States are mainly beneficial.

\section{Marsh Hawk.}

The marsh hawk is one of the most valuable of the number. It can be easily distinguished by its white rump and its habit of beating low over the meadows, for it is an indefatigable mouser. Meadow mice, rabbits and squirrels are its favorite quarry.

\section{Red-Tailed Hawk, Hen Hawk.}

This name, which the bird does not deserve, is responsible for much of the false opinion regarding it. Dr. Fisher says: "While fully 66 per cent. of the red-tail's food consists of in jurious mammals, not more than 7 per cent. consists of poultry, and it is probable that a large proportion of the poultry and game captured by it and the other buzzard hawks is made up of old, diseased or otherwise disabled fowls, so preventing their interbreeding with the sound stock and hindering the spread of fatal epidemics." A mong other things, the red-tail eats ground squirrels, rabbits, mice and rats.

\section{Red-Shouldered Hawk.}

This useful bird's list of food includes mice, snakes, grasshoppers, earthworms, snails, spiders and centipedes. Ninety per cent. of its food is composed of injurious mammals and insects.

\section{Sparrow Hawk.}

Grasshoppers, crickets and other insects form the chief food of the sparrow hawk during the warm months, and mice during the rest of the year.

\section{Swainson's Hawk.}

This bird is the great grasshopper destroyer of the West. It is estimated that in a month 300 of these birds-and they go in large flocks-save sixty tons of produce that the grasshoppers would destroy. 


\section{Long-Eared Owl.}

The long-eared owi is an industrious mouser and molests comparatively few birds. As it is one of the commonest owls, the good it does must be very great.

\section{Barred Owl.}

Althongh this bird has a bad reputation, only 4 per cent. of its food is poultry and game, and if the chicktns were shut up at night it would not do even this amount of harm. Most of its food is made up of small mammals, many of them the worst enemies we have. It also eats large numbers of injurious insects.

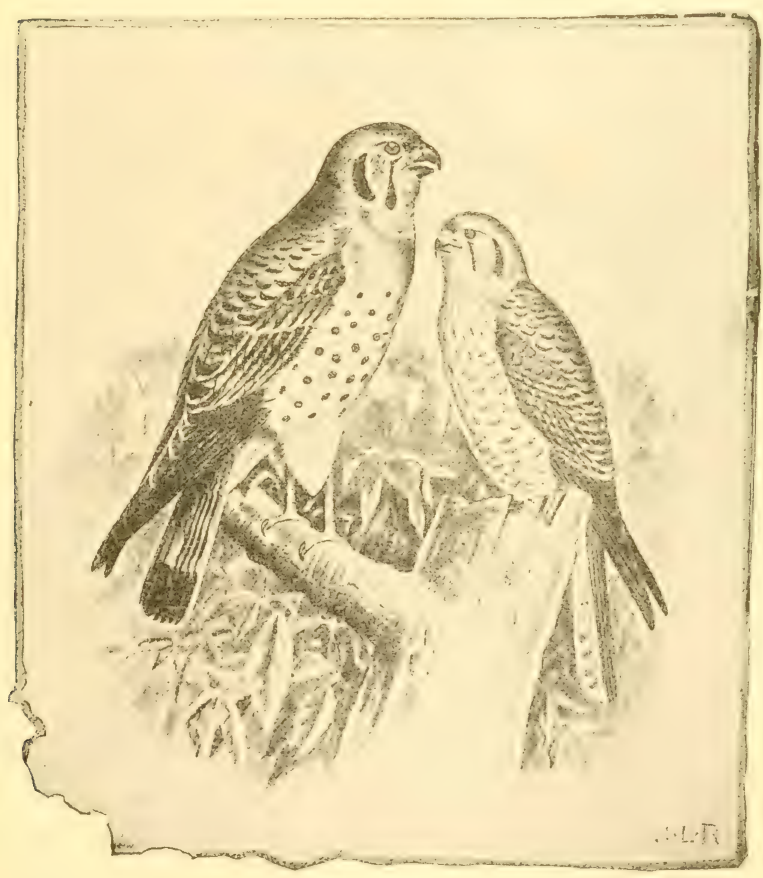

SPARROW HAWES. 


\section{Screech Owl。}

Nearly three-fonths of its food is of injurious mam. mals and insects, including grasshoppers, crickets and cutworms, mice and rats.

\section{Barn Owi.}

The food of the barn owl consists almost exclusively of nammals, such as gophers, the common rat and cotton rat, mice and shrews. From the nest of one pair of owls 154. skulls wer' taken, of which 225 were meadow mice and 179 house mice. Six hundred and seventy-five "pel. lets" or rejfcts of the barn owl, taken from one of tha inwers of the Smithsonian Institution by Dr. A. K. Fisher, contained the zemains of 1821 mammals, birds and batrachians, as follows: Rabbits 1 , rats 134 , mice 1.596 , short-tailed slirews 54 , moles 1 , bats 1 , small birds 32 , frogs \%. In other words, mice constituted 93 per cent. of the food of these owls.

\section{English Sparrow.}

It seems remarkable that the sparrow should ever have been introduced into the United States, for the English bad already been fifty years in trying to destroy the pest; and in Australia the in jury done by thespariow had been so serious that the bird became the dominant factor in politics, an election hanging on the question of its ex. termination, and the leaders who stood for its active de. struction winning the day.

In the United States we are reaping the results of our own ignorance and folly. Since the bird was introduced in 1850 it has become established in thirty-five States and five Territories, and has done its worst in driving away our native birds and destroying buds, blossoms, fruit and grain.

It has been shown to incerfere with seventy kinds of our own birds, most of which nesi about houses and gar. dene and are beneficial to the farm and garden. The ex. amination of 522 siomachs shows that, while it eats wheat, oats and corn, it has little incerest in insects. Of the insects which it has been found to eat, forty-soven kinds are harmful, while sift are beneficial, which shows how much good is to be expected from it in destroying peste to counterbalance what it does in driving away our own birds that live on insects.

It is clear that the English sparrow should be exter. minated, that laws protecting him should be repealed, and that some intelligent, systematic action should be akn to rid the Trited States of his opnoxinng preacnce. 
Bounty laws canuot do this, for, as has been clearly de. monstrated, they do more mischief than can easily be remedied, as money is usually spent on the heads of the valuable birds that have been mistaken. for the injurious ones. Small boys also are likely to do more harm than good by destroying the wrong birds. But the work might be effectively done by State boards or commissioners, who should hire trained assistants to destroy the birds and their nests.

\section{Conclusion.}

So far as it has gone, the examination of the stomach contents of birds has proved that, except in rare cases, where individuals attack cultivated fruits and grains, our native birds merely preserve the balance of nature by destroying weeds that plague the farmer and by checking the insects that destroy the produce of the agriculturist. The great value of birds is demonstrated. The question is first how to attract thew where they have disappeared, and then how to protect the crops from their occasional depredations. Mr. Forbush, who has experimented in the matter in Massachusetts, both fed the birds and planted bushes to attract them. He says; "It is evident that a diversity of plants which encourages diversified insect life and assures an abundance of fruits and seeds as an attraction to birds will insure their presence,"

The cultivated crops can be protected in two ways: either by mechanical devices that frighten the birds away from the fruit or grain fields, or by the sulistitution of wild or cultivated kinds. To frighten the birds away, white twine can be strung across berry beds, string hung with bits of glittering waste tin over felds, while stuffed hawks and cats can be kept in orchards. To attract the birds from cultivated fruit it is well to plant some wild fruit that will bear during tho weeks when the birds eat the garden or orchard crops. In this connection. Mr. For bush says: "I wish particularly to note the fact that the mulberry trees, which ripen their berries in June, proved. to be a protection to the cultivated cherries, as the fruit. eating birds seem to prefer them to the cultivated cherries, perhaps because they ripen somewhat earlier"; and he adds, "I believe it would be wise for the farmer to plant rows of these trees near his orchard, and it is possible that the early June bexry or shadberry might also be useiul in this respect."

Prof. Beal suggests planting berry bushes along the roaas and rences and̉ botween grain fielảs. 
To protect strauberries and cherries (May and June), plant Russian nulberry and June berry or shadberry.

To protect raspberries and blacleberries (July and August), plant mulberry, buckthorn, elder and choke cherry.

To protect apples, peaches, grapes (September and October), plant choke cherries, elder, wild black cherry and Virginia creeper.

To protect uinter fruits, plant Virginia creeper, dogwood, mountain asb, bittersweet, viburnum, hackberry, bayberry and pokeberry.

IIulberries are eaten by the flycatchers, warblers, vireos, cuckoos, blackbirds, orioles, finches, sparrows, tanagers, waxwings, catbirds, bluebirds and thrushes.

Potato beetles are eaten by the rose-breasted grosbeak, cuckon and quail.

Tent caterpillars (which do most harm to apple and cherry trees) are eaten by the crow, chickadee, oriole, red-eyed vireo, yellow-billed cuckoo, black-billed cuckoo, chipping sparrow and yellow warbler.

Cut worms (which cut off corn, etc., before it is fairly started in the spring, and are $v \in$ ry destructive to grass) are eaten by the robin, crow, catbird, loggerhead shrike, house wren, meadow lark, cowbird, B $ı 1$ timore oriole, brown thrasher and red-winged blackbird.

Ants (which spread plant-lice, destroy timber and infest houses) are the favorite food of the catbird, thrasher, hnuзя wren and woodpeckers; and are eaten by almost all land birds except birds of prey.

Scale insfets (which are a fruit-tree p'st, injuring oranges, olives, etc.) are caten by the bush tit, woodpeckers and cedar bird.

The MIay beetle (which ravages forest trees, and also in. jures grain and grass lands) is eaten by the hermit thrush, wood thruch, robin, meadow lart, brown thrasher, bluebird, catbird, bluejay, crow blackbird, crow, loggerhead shrike, mockingbird and gray-cheeked thrush.

Weevils (which injure grain, forage and market gardens) are eaten by the crow, crow blackbird, red-winged blackbird, Baltimore oriole, catbird, brown thrasher, house wren, meadow lark, cowbird, bluebird, robin, swallows, flycatchers, mockingbird, woodpeckers, wood thrush, Alice's thrush and scarlet tanager.

The chinch bug (which eats grain and wheat) is eaten by the brown thrasher, meadow lark, catbird, red-eyed vireo, robin and Bob White.

The wire wom (which causes heavy losses in the cornfield) is eaten by the red-winged blackbırd, crow black- 
bird, crow, woodpeckers, brown thrasher, scarlet tanager, robin, catbird, Baltireore oriole, meadow lark and cowbird.

Crane flies (which eat grass roots in the hay fields) are eaten by the robin, catbird, wood thrush, gray-cheeked thrush, olive-backed thrush, crow, crow blackbird and red-winged blackbird.

The soldier bug is eaten by the robin, bluebird, crow blackbird, crow, catbird, house wren, red-winged blackbird, Baltimore oriole and meadow lark.

Cotton worms are eaten by the bluebird, bluejay, redwinged blackbird, thrush, prairie chicken, quail, kildee, bobolink, mockingbird, cardinal and cuckoo.

Gypsy moth.-Mr. Forbush, ornithologist of the Massachusetts State Board of Agriculture, gives the following list of birds seen to feed on the gypsy moth: Yellow-billed cuckoo, black-billed cuckoo, hairy woodpecker, downy woodpecker, pigeon woodpecker, kingbird, great crested flycatcher, phobe, wood pewee, least flycatcher, bluejay, crow, Baltimore oriole, purple grackle or crow blackbird, chipping sparrow, chewink, rose breasted grosbeak, indigo bird, scarlet tanager, red-eyed vireo, yellow-throated vireo, white-eyed vireo, black-and-white warbler, yellow warbler, chestnut-sided warbler, black-throated green warbler, oven bird, Maryland yellow-throated warbler, American redstart, catbird, brown thrasher, house wren, white-breasted nuthatch, chickadee, wood thrush, American robin, bluebird and English sparrow.

Grasshoppers and crickets are eaten by the mockingbird, thrasher, bluebird, wrens, shore lark, goldfinch, longspur, grasshopper sparrow, song sparrow, junco, lark sparrow, dickcissel, rose-breasted grosbeak, blue grosbeak, indigo bunting, cardinal, chewink, bobolink, cow bird, red-winged blackbird, meadow lark, Baltimore oriole, orchard oriole, rusty blackbird, crow, bluejay, kingbird, crow blackbird, whippoorwill, night hawk, swift, cuckoo, red-headed woodpecker, flicker, barn owl, greathorned owl, marsh hawk, sparrow hawk, gulls, Swainson's hawk, quail, shrikes, swallows, vireos, robin and catbird. Army worm. - In the Massachusetts Crop Report for July, 1896, Mr. William R. Sessions gives a list of the birds he has seen feeding on the army worm during the present summer: Kingbird, phoebe, bobolink, cowbird, red-winged blackbird, Baltimore oriole, crow blackbird, chipping sparrow, robin. 
LIBRARY OF CONGRESS

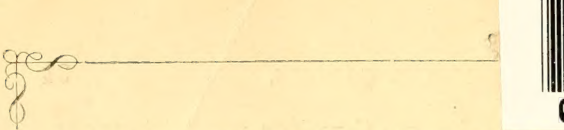

\section{FOR THE HOME TABLE.}

Forest and Stream goes into the homes of thousands of families, and is read by old and young alike, particularly the Natural History columns, which give notes and observations of bird life and bird ways. There is no better way to stimulate a boy's intelligent interest in birds than to make him a reader of Forest and Stream.

The Forest and Stream believes in the recreation to be found in the haunts of deer and grouse, and trout and bass. It believes in the common sense that calls a halt in business drive and professional grind, for a holiday with gun or rod or paddle-if only that afterward one may drive the faster and grind the harder. It is a journal for those who love the country and life out of doors. It reflects the spirit and records the experiences of the great army of outers. If you have any sympathy with these things, you may be sure that the Forest and Stream is just the paper you would like to have come into your house every week.

Ten cents per copy, $\$ 4.00$ per year.

FOREST AND STREAM PUBLISHING CO. 346 Broadway, New York. 



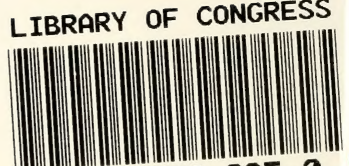

00008909350 